\title{
Frusemide in Heart Failure of Infancy
}

\author{
HEATHER RICHARDSON \\ From Guy's Hospital and the Institute of Diseases of the Chest, London
}

\begin{abstract}
Richardson, Heather (1971). Archives of Disease in Childhood, 46, 520. Frusemide in heart failure of infancy. Twelve infants with heart failure and one with perinatal oedema were treated with intramuscular frusemide $(1 \cdot 0-1 \cdot 25 \mathrm{mg} / \mathrm{kg})$. Frusemide was found to be a safe effective diuretic in infants with heart failure, resulting in clinical improvement, marked excretion of water, sodium, and chloride, with a lesser and more variable effect on potassium excretion. Complications were uncommon with this dose. The drug is most effective in acute pulmonary oedema or acute worsening of heart failure, but day-to-day control of persistent heart failure is more easily obtained by using repeated doses of oral or intramuscular frusemide plus, if needed, aldactone $A$ or triamterene.
\end{abstract}

There is little quantitative information on the use of frusemide in infancy. Reimold (1964) reports on its administration to 3 infants with perinatal oedema but observed little improvement; however, one infant aged 6 weeks, with heart failure due to myocarditis, responded well to a dose of 0.4-1 $\mathrm{mg} / \mathrm{kg}$ of frusemide.

Thieffry, Joly, and Ferchiou (1969) reported a significant diuresis and natriuresis in 8 infants with congenital heart disease, and 5 infants with other causes of fluid retention. In one infant, circulatory collapse was provoked, but they concluded that frusemide was a safe effective diuretic in a dose of $0.7-1.25 \mathrm{mg} / \mathrm{kg}$. Therefore it was decided to carry out a further study to assess the usefulness of frusemide as a diuretic in a series of infants admitted with fluid retention predominantly due to heart failure.

\section{Short-term Studies}

Eleven infants aged 3 days to 6 months were studied. Details of diagnosis, sex, age on admission, and mode of presentation are given in Table I. The usual criteria for a diagnosis of heart failure were used (Lees, 1969); however, tachypnoea of more than 60 respirations per minute and cardiac enlargement on $x$-ray in patients with congenital heart disease were considered to be sufficient to make the diagnosis. Of the 11 infants, 9 were moderately to critically ill, their most striking clinical features being tachypnoea and exhaustion (Table II). Frusemide in a dose of $1 \cdot 0-1 \cdot 25 \mathrm{mg} / \mathrm{kg}$ was given intramuscularly under the following conditions.

(a) Initially, when a diagnosis of heart failure was made; (b) when deterioration in an infant's condition occurred, usually associated with increasing tachypnoea, and clinically attributed to increasing heart failure; and

Received 9 March 1971. (c) when an increase in weight of $2 \%$ total body weight occurred in a 12-hour period.

At the time of initial examination, 8 of the children had been digitalized and one had received one dose of mersalyl. During the period of the study no other diuretic therapy other than frusemide was given.

Control urines (24-hour) were obtained from all the infants on admission, and twice a week thereafter. This was relatively easy in male infants using Paul's tubing. In female infants urine collecting bags (Down Bros.) were employed with less successful results. Accordingly, accurately timed specimens without leakage were accepted, particularly in female infants, when 24 specimens were incomplete. Ward sisters, experienced in collecting urine from infants, supervised. The volumes of urine were measured, and concentrations of electrolytes, urea, creatinine, and osmolarity were estimated. Post-frusemide urine collections were started at the time of injection of frusemide and continued for 4 hours precisely. Hourly excretion rates before and after frusemide were calculated for all parameters. Blood samples were obtained during the control periods, before the 10 a.m. feed, and also just before the injection of frusemide. The values of serum electrolytes, urea, osmolarity, and occasionally creatinine were obtained. Creatinine clearances were estimated at least once during admission. The clinical state before and after administration of frusemide was noted, with particular reference to respiratory rate and weight.

\section{Long-term Study}

A long-term study was carried out on 2 infants, with heart failure, aged 21 days and 35 days. A 12-hour urine collection was started at the time of frusemide injection, followed, if possible, by a further three consecutive 12-hour urines to act as controls and minimize the effect of any diurnal variation in excretory patterns (Hellbrügge, 1960; Wesson, 1964; Dodge, 
TABLE I

Some Details of Infants in Study

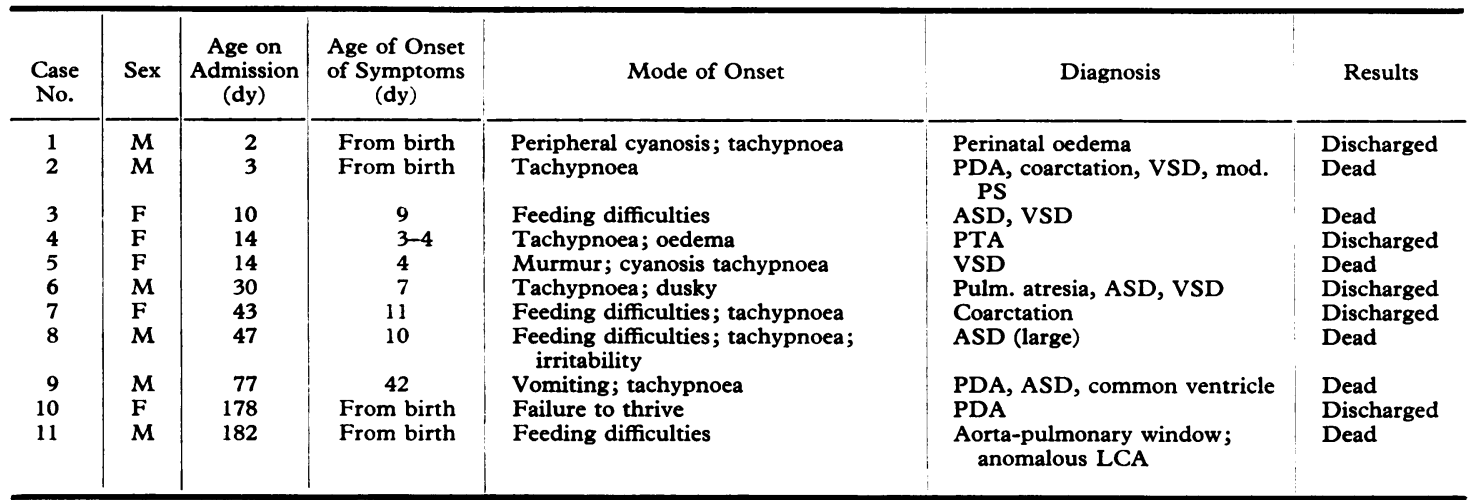

PDA, persistent ductus arteriosus; VSD, ventricular septal defect; PS, pulmonary stenosis; PTA, persistent truncus arteriosus; ASD, atrial septal defect (secundum); LCA, left coronary artery.

Travis, and Daeschner, 1967). Urine samples were analysed as above. Serum samples were obtained during the first 12-hour collection period and analysed as above.

TABLE II

Incidence of Symptoms and Clinical Findings

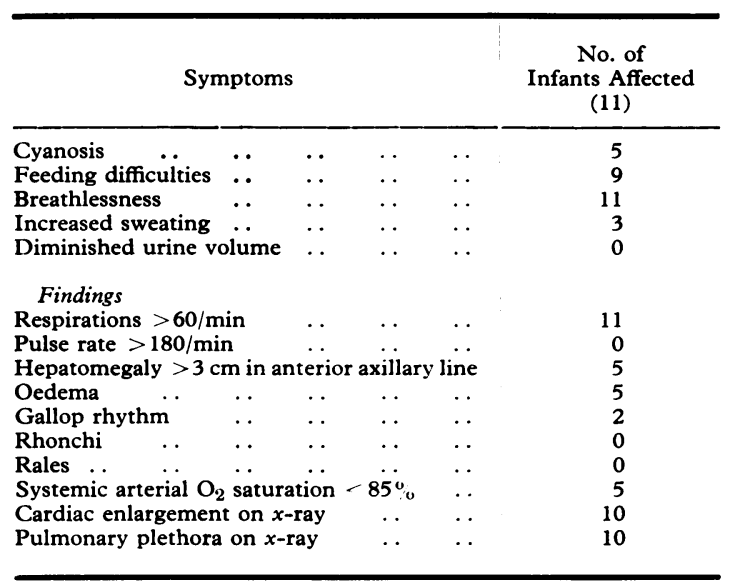

\section{Results}

Short-term results. Results are calculated from 36 control collections and 22 post-frusemide collections for urine volume and osmolarity, and from 15 control collections and 16 post-frusemide collections for sodium, potassium, and chloride, the urines having been selected from patients who were comparable for clinical state, electrolyte, and fluid intake (Table III).

Results from the two infants with persistent heart failure are discussed later.

Urine volumes. The onset of diuresis occurred at 20 to 40 minutes after the administration of frusemide. Mean hourly urine volumes increased from $8 \cdot 9 \pm 4 \cdot 1$ before frusemide to $31 \cdot 6 \pm 13 \cdot 9$ $\mathrm{ml}$ per hour after frusemide $(P<0.001)$.

Sodium excretion. Mean hourly sodium excretion increased from $203 \pm 139 \mu \mathrm{Eq} /$ hour before frusemide to $2132 \pm 1769 \mu \mathrm{Eq} /$ hour after frusemide $(\mathrm{P}<0.001)$.

Potassium excretion. Mean hourly potassium excretion increased from $347 \pm 231 \mu \mathrm{Eq} /$ hour before frusemide to $795 \pm 741 \mu \mathrm{Eq}$ after frusemide

TABLE III

Mean Changes in Urinary Constituents Before and After Frusemide

\begin{tabular}{|c|c|c|c|c|c|c|c|c|}
\hline & $\begin{array}{l}\text { Mean } \\
\text { Urine } \\
\text { Vol. } \\
(\mathbf{m l} / \mathbf{h r})\end{array}$ & $\begin{array}{c}\text { Mean } \\
\text { Na } \\
\text { Excretion } \\
(\mu \text { Eq } / \mathbf{h r})\end{array}$ & $\begin{array}{c}\text { Mean } \\
\mathbf{K} \\
\text { Excretion } \\
(\mu \text { Eq/hr })\end{array}$ & $\begin{array}{l}\text { Mean } \\
\mathrm{Na} / \mathrm{K} \\
\text { Ratios }\end{array}$ & $\begin{array}{c}\text { Mean } \\
\text { Cl } \\
\text { Excretion } \\
(\mu \mathrm{Eq} / \mathrm{hr})\end{array}$ & $\begin{array}{c}\text { Mean } \\
\text { Osmolarity } \\
(\mathrm{mOsm} / \mathrm{l} .)\end{array}$ & $\begin{array}{c}\text { Mean } \\
\text { Osmolar } \\
\text { Clearance } \\
(\mathrm{ml} / \mathrm{hr})\end{array}$ & $\begin{array}{c}\text { Mean } \\
\text { Free Water } \\
\text { Clearance } \\
(\mathrm{ml} / \mathrm{hr})\end{array}$ \\
\hline $\begin{array}{l}\text { Prefrusemide values } \\
\text { Postfrusemide values } \\
\text { P }\end{array}$ & $\begin{array}{c}8 \cdot 9 \pm 4 \cdot 1 \\
31 \cdot 6 \pm 13 \cdot 9 \\
<0 \cdot 001\end{array}$ & $\begin{array}{c}203 \pm 139 \\
2132 \pm 1769 \\
<0.001\end{array}$ & $\begin{array}{c}347 \pm 231 \\
795 \pm 741 \\
\text { N.S. }\end{array}$ & $\begin{array}{c}0 \cdot 5 \pm 0 \cdot 2 \\
4 \cdot 1 \pm 2 \cdot 1 \\
<0 \cdot 001\end{array}$ & $\begin{array}{c}229 \pm 164 \\
2875 \pm 2173 \\
<0.001\end{array}$ & $\begin{array}{c}345 \pm 202 \\
229 \pm 79 \\
<0.01\end{array}$ & $\begin{array}{c}8 \cdot 4 \pm 5 \cdot 6 \\
23 \cdot 0 \pm 15 \cdot 7 \\
<0 \cdot 001\end{array}$ & $\begin{array}{l}-0 \cdot 8 \pm 4 \cdot 4 \\
5 \cdot 2 \pm 8 \cdot 6 \\
<0 \cdot 001\end{array}$ \\
\hline
\end{tabular}


$(P>0.05)$. Potassium loss tended to increase with increasing urine volumes. There was no correlation between excessive potassium loss and age, and excessive potassium loss might or might not occur in the same patient.

Sodium potassium ratios $(\mathrm{Na} / \mathrm{K})$. Mean $\mathrm{Na} / \mathrm{K}$ ratio increased from $0.5 \pm 0.2$ before frusemide to $4 \cdot 1 \pm 2 \cdot 1$ after frusemide $(P<0 \cdot 001)$, indicating that the urinary loss of sodium is much greater than that for potassium.

Chloride excretion. Mean chloride excretion increased from $229 \pm 164 \mu \mathrm{Eq} /$ hours before frusemide to $2875 \pm 2173 \mu \mathrm{Eq} /$ hour after frusemide ( $\mathbf{P}<0.001)$.

Urine osmolarity. Mean urine osmolarity decreased from $345 \pm 202 \mathrm{mOsm} / 1$. before frusemide to $229 \pm 79 \mathrm{mOsm} / \mathrm{l}$. after frusemide $(\mathrm{P}<0 \cdot 01)$.

Osmolar clearance. Mean osmolar clearance increased from $8.4 \pm 5.6 \mathrm{ml} /$ hour before frusemide administration to $23.0 \pm 15 \cdot 7 \mathrm{ml} / \mathrm{hour}$ after frusemide $(P<0.001)$.

Free water clearance. Mean free water clearance increased from $-0.8 \pm 4.4 \mathrm{ml}$ per hour before frusemide to $5 \cdot 2 \pm 8 \cdot 6$ after frusemide $(P<0 \cdot 001)$.

Creatinine clearances. Creatinine clearances ranged from $5 \cdot 2-33 \mathrm{ml} / \mathrm{min}$ per $1 \cdot 73 \mathrm{~m}^{2}$.

Clinical. Oedema, which was present in 5 infants, cleared rapidly. The 2 infants (Cases 7 and 10) with excessive weight gain and tachypnoea responded well to intramuscular frusemide. Thereafter heart failure was controlled by digoxin and restricted fluid and sodium intake until corrective surgery was undertaken. One infant (Case 4) with persistent truncus arteriosus also responded well to one injection of frusemide and was discharged home well controlled on digoxin and restricted fluid and sodium intake. The remaining 8 infants improved slightly or their condition did not deteriorate further; however in 12 to 24 hours they lost all benefit from the diuretic, as judged by their clinical state, particularly respiratory rate and weight.

Two patients developed collapse of a lobe of a lung after diuretic therapy, possibly related to loss of intrapulmonary fluid.

Long-term studies. Results from only one of the patients are presented in detail, as they were similar in the two patients. Intermittent intramuscular frusemide was extremely effective in promoting increase in urine volume (from a mean of $5.9 \pm 2.9$ to $14.8 \pm 1.8 \mathrm{ml} /$ hour $(P<0.001))$ and sodium excretion (from a mean of $105 \pm 127$ to $722 \pm 263 \mu \mathrm{Eq} /$ hour, $P<0.001)$. Frusemide had a lesser effect on promoting potassium excre- tion (mean increase from $276 \pm 115 \mu \mathrm{Eq} /$ hour to $319 \pm 83 \mu \mathrm{Eq} /$ hour $P<0.001)$. Urea and creatinine excretion were not significantly affected. Urine osmolarity decreased from $395 \pm 197 \mathrm{mOsm} /$ 1. to $206 \pm 73 \mathrm{mOsm} / \mathrm{l}$. $(\mathbf{P}<0.005)$. Osmolar clearance increased from $1.3 \pm 0.9$ to $1.6 \pm 0.5$ $\mathrm{ml} / \mathrm{hr}(\mathrm{P}>0.05)$ and free water clearances increased from $-0.40 \pm 0.85$ to $0.64 \pm 0.65(P<0.001)$. The falls that occurred in weight and respiratory rate are shown in the Fig. and correlated well with the observed clinical improvement.

Mild hyponatraemia, moderate hypochloraemia, occasional hypokalaemia, and very occasionally a rise in blood urea were noted and attributed to frusemide therapy. Serious dehydration and extracellular alkalosis did not occur.

\section{Discussion and Comment}

In structure, frusemide is a saturated benzene ring with attached sulphamyl and chlorine groups. In human adults peak plasma levels of sulphur-35 labelled frusemide were found at 30 minutes after intramuscular administration, and 60 minutes after oral administration; approximately $80 \%$ of the labelled dose being recovered in the urine after intravenous and intramuscular administration (Calesnick, Christensen, and Richter, 1966). It is rapidly excreted in adults by filtration and tubular secretion in the urine (Deetjen, 1966), and it is also excreted in the bile and faeces (Schirmeister and Willmann, 1964). Excretion of frusemide like other drugs may be slower in the newborn.

The diuretic action of frusemide may well be brought about by a lowering of the permeability of cell membranes for ions, thus reducing passage of ions from the lumen of the tubule (Nagel and Karger, 1964). Decreased permeability to ions has been shown by Lipson and Hays (1966) in the toad bladder; and Holzgreve et al. (1965) using a continuous microperfusion technique found that sodium efflux out of both proximal and distal tubules was inhibited by frusemide.

A fall in glomerular filtration rate (GFR) occurs in normal subjects with frusemide, probably accounted for by the accompanying fall in extracellular fluid (Stein and Kirkendall, 1967). However, frusemide is an effective diuretic even in the presence of greatly impaired renal function (Vorburger, 1964; Muth, 1966; Reubi, 1966), and Vorburger (1964) has observed increases in GFR in patients in renal failure, with frusemide. A marked rise in renal blood flow occurs with frusemide (Schirmeister and Willmann, 1964; Vorburger, 1964; and Hook et al., 1966). Barger (1966) and 


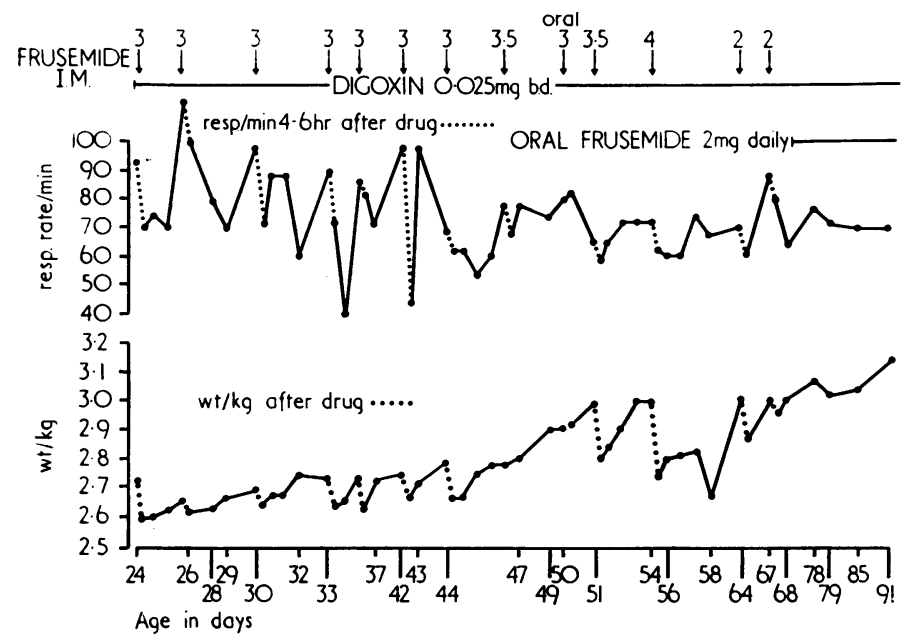

FIG.-Effect of frusemide on respiratory rate and weight. The data are taken from a patient with persistent ductus arteriosus, coarctation of the aorta, mitral stenosis, ventricular septal defect, and congestive heart failure. The fall that occurred in respiratory rate 4-6 hours after frusemide and the fall in weight that occurred 4-8 hours after frusemide are clearly seen. These falls correlated well with observed clinical improvement. The tendency for respiratory rate and weight to return to pre-frusemide values with intermittent treatment is also seen.

Barger and Herd 1967) found that, in dogs, frusemide increased cortical blood flow at the time of diuresis, and lowered renal vein resistance, thus reversing the situation that occurs in heart failure (Birtch et al., 1967).

Frusemide exerts only a net slight inhibition on the proximal tubule, the inhibition of the intrinsic reabsorptive capacity being almost negated by the resultant rise in intraluminal pressure (Dirks, Cirksena, and Berliner, 1966; Rector et al., 1966).

The predominant site of action in the renal tubule is probably the ascending loop of Henle, as shown by the drug's interference with the concentrating mechanism (Buchborn and Anastasakis, 1964; Suzuki, Klütsch, and Heidland, 1964; Gayer, 1965; Lezotte et al., 1966; Deetjen, 1966). Potassium loss occurs primarily because of increased distal tubular secretion of potassium, and this loss may be augmented in situations where there is increased aldosterone secretion (Cannon et al., 1965; Stason et al., 1966).

As in adults, frusemide was found to be an effective diuretic and natriuretic in infants with low glomerular filtration rates; as indicated by the low creatinine clearances observed (perinatal oedema from age of 3 days, and heart failure from age of 6 days). A significant rise in free water clearance was observed after frusemide, which suggested a proximal site of action; and also urine osmolarity of the post-frusemide samples was significantly lower than control period samples, suggesting that interference with the medullary concentration gradient occurred and that frusemide acted on the ascending loop of Henle (Seldin et al., 1966; Suki, Rector, and Seldin, 1965; Berliner, Dirks, and Cirksena, 1966).

Unlike the results of Reimold (1964), who stated that increased elimination of potassium can be expected only at doses above $2.5 \mathrm{mg} / \mathrm{kg}$, increased elimination of potassium occurred in our patients in 8 out of 10 instances, when diuresis exceeded 20 $\mathrm{ml} / \mathrm{hr}$; this may relate to the size of the diuresis.

Intramuscular frusemide was shown to be a potent diuretic in infants with heart failure, and because of its ease of administration, speed of action, and lack of toxicity, is one of the diuretics of choice for the initial treatment of heart failure. However, as infants tend to lose all benefit from the drug in 12 to 24 hours, persistent heart failure is more easily controlled by twice daily administration of frusemide, and if heart failure is still uncontrolled drugs with a distal tubular site of action such as aldactone $\mathrm{A}$ or triamterene might be given in addition.

This work was supported by the Guy's Hospital endowment fund, and the Dunhill fund, Institute of Diseases of the Chest. I am grateful to Dr. J. Liddell (Guy's Hospital) and Mrs. O'Hanlon (Brompton Hospital) for carrying out the biochemical estimations, to the house staff and nursing staff for their unfailing co-operation, to Dr. M. C. Joseph, Dr. Stewart 
Cameron, and Dr. C. Chantler for their help in preparing this paper, and to Dr. J. F. Richardson for statistical analysis.

\section{REFERENCES}

Barger, A. C. (1966). Renal hemodynamic factors in congestive heart failure. Annals of the New York Academy of Sciences, $139,276$.

Barger, A. C., and Herd, J. A. (1967). Studies of the renal circulation in the unanaesthetised dog with inert gases. 1. External counting. In Proceedings of the IIIrd International Congress of Nephrology, 1966, Vol. 1, p. 95. Karger, Basle and New York.

Berliner, R. W., Dirks, J. H., and Cirksena, W. J. (1966). Action of diuretics in dogs studied by micropuncture. Annals of the New York Academy of Sciences, 139, 424.

Birtch, A. G., Zakheim, R. M., Jones, L. G., and Barger, A. C. (1967). Redistribution of renal blood flow produced by furosemide and ethacrynic acid. Circulation Research, 21, 869.

Buchborn, E., and Anastasakis, S. (1964). Angriffspunkt und Wirkungsmechanismus von Furosemid am distalen Nephron des Menschen. Klinische Wochenschrift, 42, 1127.

Calesnick, B., Christensen, J. A., and Richter, M. (1966). Absorption and excretion of furosemide-S35 in human subjects. Proceedings of the Society for Experimental Biology and Medicine, 123, 17.

Cannon, P. J., Heinemann, H. O., Stason, W. B., and Laragh, J. H. (1965). Ethacrynic acid. Effectiveness and mode of diuretic action in man. Circulation, 31, 5.

Deetjen, P. (1966). Micropuncture studies on site and mode of diuretic action of furosemide. Annals of the New York Academy of Sciences, $139,408$.

Dirks, J. H., Cirksena, W. J, and Berliner, R. W. (1966). Micropuncture study of the effect of various diuretics in sodium reabsorption by the proximal tubules of the dog. Fournal of Clinical Investigation, 45, 1875.

Dodge, W. F., Travis, L. B., and Daeschner, C. W. (1967). Comparison of endogenous creatinine clearance with inulin clearance. American Fournal of Diseases of Children, 113, 683

Gayer, J. (1965). Die renale exkretion des neuen Diureticum Furosemid. Klinische Wochenschrift, 43, 898.

Hellbrügge, T. (1960). The development of circadian rhythms in infants. Cold Spring Harbour Symposium on Quantitative Biology, 25, 311.

Holzgreve, H., Frick, A., Rumrich, G., Wiederholt, M., and Ullrich, K. J. (1965). Wirkungweise von Diuretica auf dem transtubulasen Transport von natriumchlorid. In Normale und pathologische funktionen des nierentubulus, p. 147. K. J. Ullrich and K. Hierholzer. Hans Huber, Bern.

Hook, J. B., Blatt, A. H., Brody, M. J., and Williamson, H. E. (1966). Effects of several saluretic-diuretic agents on renal hemodynamics. Fournal of Pharmacology and Experimental Therapeutics, 154, 667.

Lees, M. H. (1966). Catecholamine metabolite excretion of infants with heart failure. Fournal of Pediatrics, 69, 259.

Lees, M. H. (1969). Heart failure in the newborn infant. fournal of Pediativics, 75, 139.
Lezotte, L. A., MacGaffey, K. M., Moore, E. W., and Jick, H. (1966). The effect of frusemide on renal concentration and dilution. Clinical Science, 31, 371.

Lipson, S., and Hays, R. M. (1966). The effect of ethacrynic acid and furosemide on sodium transport and ionic permeability in the toad bladder. (Abst.) fournal of Clinical Investigation, 45, 1042.

Muth, R. G. (1966). Diuretic response to furosemide in the presence of renal insufficiency. Fournal of the American Medical Association, 195, 1066.

Nagel, W., and Karger, W. (1964). Die Wirkung von 4 Chloro N (2 furylmethyl) 5 sulfmoylanthrandsaure (lasix) auf conenaktive Membranen. Autoref 29 Tagg Deutsche Physiol Ges Tubingen.

Rector, F. C., Jr., Brunner, F. P., Sellman, J. C., and Seldin, D. W. (1966). Pitfalls in the use of micropuncture for the localization of diuretic action. Annals of the New York Academy of Sciences $139,400$.

Reimold, E. (1964). Trials and clinical experiences with frusemide in infants and children. Hoechst Company. Personal communication.

Reubi, F. C. (1966). Clinical use of furosemide. Annals of the New York Academy of Sciences, 139, 433.

Schirmeister, J., and Willmann, H. (1964). Über die Harnsäureund andere Clearances nach intravenöser Gabe von Fursemid beim Menschen. Klinische Wochenschrift, 42, 623.

Seldin, D. W., Eknoyan, G., Suki, W. N., and Rector, F. C., Jr. (1966). Localization of diuretic action from the pattern of water and electrolyte excretion. Annals of the New York Academy of Sciences, 139, 328.

Stason, W. B., Cannon, P. J., Heinemann, H. O., and Laragh, J. H. (1966). Furosemide. A clinical evaluation of its diurectic action. Circulation, 34, 910.

Stein, J. H., and Kirkendall, W. M. (1967). New diuretics. Fournal of the Iowa Medical Society, 57, 1012.

Suki, W., Rector, F. C., Jr., and Seldin, D. W. (1965). The site of action of furosemide and other sulphonamide diuretics in the dog. Fournal of Clinical Investigation, 44, 1458.

Suzuki, F., Klütsch, K., and Heidland, A. (1964). Stop-flowUntersuchungen zum Wirkungsmechanismus von Fursemid. Klinische Wochenschrift, 42, 569.

Thieffry, S., Joly, J. B., and Ferchiou, A. (1969). Intérêt d'un diurétique à action rapide (furosemide) en réanimation du nouveau-ne et du nourrisson. Revue de Pédiatrie, 5, 49.

Vorburger, C. (1964). Die Akute Wirkung des Diureticums Fursemid auf das Glomerulumfiltrat, die renale Hämodynamik, die Wasser-, natrium- Chlorid-und Kaliumausscheidung und auf den Sauerstoffverbrauch der Nieren. Klinische Wochenschrift, 42, 833.

Wesson, L. G., Jr. (1964). Electrolyte excretion in relation to diurnal cycles of renal function. Medicine, 43, 547.

Correspondence to Dr. Heather Richardson, Paediatric Department, Institute of Diseases of the Chest, Fulham Road, London S.W.3. 